\title{
PENGARUH STRATEGI PEMBELAJARAN PENINGKATAN KEMAMPAUN BERPIKIR DAN KEMAMPUAN AWAL TERHADAP HASIL BELAJAR APRESIASI SASTRA
}

\author{
Amlan, Harun Sitompul, Sahat Siagian \\ Sekolah Menengah Pertama Negeri 2 NA IX-X Kabupaten Labuhan Batu Utara \\ amlanlubis@yahoo.com
}

\begin{abstract}
Abstrak: Penelitian ini bertujuan untuk mengetahui; (1) perbedaan hasil belajar apresiasi karya sastra prosa fiksi antara siswa yang dibelajarkan dengan SPPKB dan siswa yang dibelajarkan dengan strategi ekspositori (2) perbedaan hasil belajar apresiasi karya sastra prosa fiksi antara siswa yang kemampuan awal apresiasi karya sastra prosa filksinya tinggi dengan yang kemampuan awal apresiasi karya sastra prosa fiksinya rendah. (3) interaksi antara strategi pembelajaran dan kemampuan awal apresiasi karya sastra prosa fiksi siswa terhadap hasil belajar apresiasi karya sastra prosa fiksi siswa. Metode penelitian quasi eksprimen dengan desain factorial 2x2. Teknik analisis data ANAVA. Hasil penelitian menunjukkan bahwa: (1) hasil belajar apresiasi karya sastra prosa fiksi siswa yang dibelajarkan dengan SPPKB lebih tinggi daripada yang dibelajarkan dengan strategi ekspositori, (2) hasil belajar apresiasi karya sastra prosa fiksi yang memiliki kemampuan awal tinggi lebih tinggi daripada yang kemampuan awalnya rendah, dan (3) terdapat interaksi antara strategi pembelajaran dan kemampuan awal terhadap hasil belajar apresiasi karya sastra prosa fiksi siswa.
\end{abstract}

Kata Kunci: strategi pembelajaran peningkatan kemampuan berpikir, kemampuan awal, apreasi sastra

Abstract: This study aims to find out; (1) differences in learning outcomes of fiction prose literature appreciation between students who are taught with SPPKB and students who are taught with expository strategies (2) differences in learning outcomes in appreciation of fiction prose literary works between students whose initial ability of appreciation of prose fils literature is high with initial abilities appreciation of his fiction prose literary works are low. (3) the interaction between learning strategies and the initial ability of appreciation of students 'fiction prose literary works towards the results of learning of students' appreciation of fiction prose literature. Quasiexperimental research method with $2 \times 2$ factorial design. ANOVA data analysis technique. The results of the study show that: (1) the learning outcomes of the appreciation of fiction prose literary works of students who are taught with SPPKB are higher than those learned with expository strategies, (2) the learning outcomes of appreciation of fiction prose literary works that have higher initial abilities are higher than those with initial abilities low, and (3) there is an interaction between learning strategies and initial abilities towards learning outcomes of students' appreciation of fiction prose literature.

Keywords: learning strategies to increase thinking ability, initial ability, literary creation

\section{PENDAHULUAN}

Standar kompetensi tentang bidang apresiasi sastra telah terintegrasi ke dalam empat aspek keterampilan berbahasa yaitu mendengarkan, berbicara, membaca, dan menulis. Untuk kelas VIII SMP telah tercantum pada Standar Isi 2006 mata pelajaran Bahasa Indonesia yaitu; memahami unsur intrinsik novel remaja (asli atau terjemahan), mengapresiasi kutipan novel remaja (asli atau terjemahan), dan memahami buku novel remaja (asli atau terjemahan). Sedangkan kompetensi dasarnya adalah (1) mengidentifikasi karakter tokoh novel remaja (asli atau terjemahan), (2) menjelaskan tema dan latar novel remaja (asli atau terjemahan), (3) mendeskripsikan alur novel remaja (asli atau terjemahan), (4) mengomentari kutipan novel remaja (asli atau terjemahan), (5) menanggapi hal yang menarik dari kutipan novel remaja (asli atau terjemahan), (6) menjelaskan alur cerita, pelaku, dan latar novel remaja(asli atau terjemahan), dan (7) mengenali ciri-ciri umum puisi dari buku antologi puisi. 
Kenyataan tentang permasalahan pembelajaran apresiasi sastra juga dikemukan oleh Hasanuddin dalam makalahnya pada seminar nasional tentang kompetensi dan profesionalisme guru Bahasa dan Sastra Indonesia di Unimed. Beliau mengatakan meskipun berbagai usaha telah dilakukan oleh banyak pihak untuk meningkatkan kualitas hasil pembelajaran apresiasi sastra, namun buktibukti dilapangan menunjukkan belum ada kemajuan yang signifikan. Menurut beliau perlu dilakukan pembaharuan-pembaharuan pembelajaran karena tanpa itu pemasalahan tentang pembelajaran apresiasi sastra tidak akan teratasi.

Salah satu upaya yang dapat dilakukan untuk mengatasi permasalahan tersebut adalah meningkatkan kualitas pembelajaran dengan penerapan strategi pembelajaran yang tepat. Strategi pembelajaran yang dikembangkan adalah strategi pembelajaran yang berpusat pada siswa. Salah satu strategi yang dianggap tepat digunakan guru dalam pembelajaran apresiasi sastra prosa fiksi adalah Strategi Pembelajaran Peningkatan Kemampuan Berpikir (SPPKB). Strategi ini dianggap sebagai strategi yang tepat digunakan dalam pembelajaran apresiasi sastra karena strategi ini akan mengarahkan siswa untuk mengembangkan kemampuan berpikirnya.

\section{Hakikat Hasil Belajar Apresiasi Sastra}

Suryabarata (2002) menjelaskan belajar merupakan suatu peroses perubahan tingkah laku sebagai suatu hasil interaksi dengan lingkungannya dalam memenuhi kebutuhannya dengan ciri-ciri: (1) perubahan terjadi secara sadar, (2) perubahan dalam belajar bersifat kontiniu dan fungsional, (3) perubahan dalam belajar bersifat positif dan aktif, artinya perubahan itu senantiasa bertambah dan tertuju untuk memperoleh sesuatu yang lebih baik dari sebelumnya, (4) perubahan dalam belajar bukan bersifat sementara, tetapi bersifat permanen, (5) perubahan dalam belajar bertujuan terarah, dan (6) perubahan dalam belajar mencakup seluruh aspek tingkah laku.

Menurut Syah (2003) belajar adalah perolehan perubahan tingkah laku yang relatif menetap sebagai akibat latihan dan pengalaman. Menrut Arsyad (2000) salah satu pertanda seseorang itu telah belajar adalah adanya perubahan tingkah laku pada dirinya yang mungkin disebabkan oleh terjadinya perubahan tingkat pengetahuan, keterampilan, atau sikapnya.

Djamarah dan Zain (2002) menjelaskan bahwa hasil belajar adalah penguasaan peserta didik terhadap bahan/materi pelajaran yang telah diberikan ketika proses mengajar berlangsung. Sedangkan Gagne dan Briggs dalam Sujana (2002) mengemukakan bahwa hasil belajar dapat dikelompokkan ke dalam lima kategori, yaitu keterampilan intelektual, strategi kognitif, informasi formal, kemampuan motorik dan sikap.

Menurut Romizowski (1981) hasil belajar diperoleh dalam bentuk yaitu: (1) pengetahuan, dan (2) keterampilan. Pengetahuan dikelompokkan kepada empat kategori, yaitu fakta, konsep, dan prosedur. Fakta merupakan pengetahuan tentang obyek nyata yang merupakan asosiasi dari kenyataankenyataan dan informasi verbal dari suatu obyek, peristiwa atau manusia. Konsep merupakan pengetahuan tentang seperangkat obyek konkrit atau definisi. Prinsip adalah merupakan pernyataan mengenai hubungan dua konsep atau lebih, hubungan itu bisa bersifat kausalitas, korelasi atau aksiomatis. Prosedur merupakan pengetahuan tentang tindakan demi tindakan yang bersifat linier dalam mencapai suatu tujuan.

Menurut Bloom dalam Purwanto (2000) tingkat kemampuan belajar atau tipe hasil belajar yang termasuk ranah kognitif terdiri dari enam jenjang, yaitu pengetahuan, pemahaman, penerapan atau aplikasi, analisis, sintesis, dan evaluasi. Pendapat Bloom ini banyak dipakai dalam memperoleh hasil belajar siswa. Makna masing-masing tingkatan kogmnitif tersebut akan diuraikan berikut ini.

Pendapat lain tentang hasil belajar aspek kognitif dikemukakan oleh Merril (1981) mengklasifikasikan hasil belajar kognitif kedalam sepuluh bagian, yang terdiri dari empat keterampilan mengingat yaitu keterampilan mengingat fakta, konsep, prosedur, dan kaidah. Tiga keterampilan mempergunakan, yaitu keterampilan menggunakan konsep, prosedur, dan kaidah. Tiga keterampilan menemukan, yaitu keterampilan menemukan konsep, prosedur, dan kaidah.

Apresiasi sastra adalah upaya memahami karya sastra yaitu upaya untuk dapat mengerti sebuah karya sastra yang kita baca, baik prosa maupun puisi, mengerti maknanya, baik yang intensional maupun aktual, dengan cara mengerti seluk beluknya. Pendek kata, apresiasi 
sastra merupakan upaya "merebut makna" karya sastra (Teeuw, 1980) sebagai tugas utama seorang pembaca.

Kegiatan-kegiatan yang dilakukan untuk memahami karya sastra paling tidak meliputi tiga hal, yaitu interpretasi atau penafsiran, analisis, dan penilaian. Penafsiran adalah upaya memahami karya sastra dengan memberikan tafsiran berdasarkan sifat-sifat karya sastra itu sendiri.

Dalam hal ini Abrams (1981) membedakan tafsiran menjadi dua, yaitu dalam arti sempit penafsiran merupakan upaya untuk memperjelas arti bahasa dengan sarana analisis, paraphrase, dan komentar. Dalam arti luas, penafsiran adalah membuat jelas arti karya sastra yang bermediakan bahasa itu, yaitu meliputi eksplikasi atau penjelasan aspek-aspek seperti jenis karya sastra, unsur-unsur, struktur, tema, dan efek-efeknya. Analiasis adalah penguraian karya sastra atas bagian-bagian atau norma-normanya.

Secara lebih khusus analisis terhadap karya sastra dibedakan menjadi analisis fiksi dan analisis puisi. Analisis fiksi meliputi analisis terhadap semua elemen pembangun fiksi, yang mencakup fakta cerita, sarana cerita dan tema (Stanton, 1965). Fakta cerita meliputi plot, tokoh, dan latar. Sarana cerita meliputi hal-hal yang dimanfaatkan oleh pengarang dalam memilih dan menata detail-detail cerita sehingga tercipta pola yang bermakna, seperti unsur judul, sudut

\section{Hakikat Strategi Pembelajaran}

Dick dan Carey (2015) mengatakan bahwa strategi pembelajaran memuat lima komponen utama yaitu: (1) aktivitas pembelajaran pendahuluan, (2) penyampaian informasi, (3) partisipasi peserta didik, (4) tes, dan (5) kegiatan lanjutan. Suparman (2001) mendefinisikan strategi pembelajaran sebagai perpaduan dari (1) urutan kegiatan intruksional, (2) cara pengorganisasian materi pengajaran dan peserta didik, (3) peralatan dan bahan, dan (4) waktu yang digunakan dalam proses pembelajaran. Kedua definisi yang dikemukakan para ahli tersebut pada prinsipnya lebih menekankan pada aspek komponen dan prosedur pengajaran.

Romizowski (1981) berpendapat bahwa strategi pembelajaran merupakan suatu pendekatan menyeluruh yang dapat dibedakan menjadi dua strategi dasar, yaitu ekpositori (penjelasan) dan inquiri/ diskoveri (penemuan). Kedua strategi ini dapat dipandang sebagai dua ujung tombak yang sejalan dalam suatu kontinum starategi. Hal ini erat sekali kaitannya dengan pendekatan deduktif dimana strategi ini dimulai dari penyajian informasi mengenai prinsip atau kaidah kemudian diikuti dengan tes penguasaan dan penerapan dalam bentuk contoh dan penerapan pada situasi tertentu. Strategi inquiri/ diskoveri didasarkan pada teori belajar pengalaman yang disebut teori belajar pengalaman.

Hamalik (2003) mendefinisikan strategi pembelajaran sebagai sitem menyeluruh yang terdiri dari sejumlah komponen yaitu komponen masukan (input) ,komponen proses dan komponen produk (output). Dimiyati dan Moedjioni (1999) menjelaskan bahwa untuk mengoptimalkan interaksi antara peserta didik dengan komponen sistem pembelajaran lainnya, tenaga pengajar harus mengkonsistensikan tiaptiap aspek dari komponen-komponen yang membentuk sistem tersebut dan dapat melakukan hal tersebut dengan berbagai siasat. Kegiatan tenaga pengajar mengupayakan konsistensi antara aspek-aspek dari komponen pembentuk sistem pembelajaran dengan siasat tertentu inilah yang disebut dengan istilah strategi pembelajaran.

$$
\text { Merill dan Twitchell }
$$
mengklasifikasikan strategi pembelajaran atas tiga dasar (1) tujuan pengajaran meliputi seluruh kombinasi antara jenis materi dan tingkah laku yang diharapkan, (2) cara mempersentasikan materi yaitu dari tingkat yang khusus ke tingkat yang umum atau sebaliknya dari tingkat yang umum ketingkat yang khusus, dan (3) bentuk respon peserta didik dibedakan atas strategi ekspositori dan inkuiri. Romizowski (1981) menekankan bahwa setiap strategi pembelajaran yang dikembangkan selalu mencerminkan posisi teoritis yang dianut tentang bagaimana seharusnya pembelajaran itu dilaksanakan. Oleh karena itu, tenaga pengajar sebagai penyelenggara kegiatan pembelajaran dituntut mampu mengupayakan terjadinya interaksi peserta didik dengan komponen sistem pembelajaran yang lain secara optimal.

Dalam menggunakan strategi pembelajaran hal utama yang harus diperhatikan adalah karakteristik peserta didik. Seels dan Richey (1994) berpendapat bahwa karakteristik peserta didik adalah segi-segi latar belakang pengalaman yang berpengaruh terhadap efektifitas proses belajarnya. Dick dan Carey (2015) menjelaskan bahwa dalam 
pengembangan pembelajaran penting sekali mempertimbangkan karakteristik peserta didik untuk memilih pendekatan yang sesuai dengan kegiatan pembelajaran. Langkah-langkah yang ditempuh sebagai prosedur desain dan pengembangan pembelajaran, yaitu (1) analisis kebutuhan untuk mengidentifikasi tujuan pembelajaran umum, (2) Melakukan analisis intruksional, (3) menganalisis karakter peserta didik dan konteks, (4) pengembangan instrument penilaian, (5) pengembangan strategi pembelajaran, (6) mengembangkan dan memilih bahan-bahan pembelajaran, (7) merancang dan menyusun evaluasi formatif pembelajaran, (8) merancang dan menyusun evaluasi sumatif, dan (9) revisi untuk setiap langkah pengembangan pembelajaran.

\section{Hakikat Strategi Pembelajaran Peningkatan Kemampuan Berpikir}

Berdasarkan teori belajar kognitif tersebut para pakar pembelajaran telah mengembangkan berbagai strategi pembelajaran yang berpedoman pada teori belajar kognitif tersebut.Salah satu strategi pembelajaran yang dikembangkan adalah Strategi Pembelajaran Peningkatan Kemampuan Berpikir (SPPKB).

Wina Sanjaya (2008) SPPKB adalah strategi pembelajaran yang bertumpu kepada pengembangan kemampuan berpikir siswa melalui telaahan fakta-fakta atau pengalaman anak sebagai bahan untuk memecahkan masalah yang diajukan.

Berdasarkan pengertian tersebut ada bebrapa hal yang penting tentang SPPKB, yaitu (1) SPPKB adalah strategi pembelajaran yang bertumpu pada pengembangan kemampuan berpikir, artinya tujuan yang akan dicapai oleh SPPKB adalah bukan sekedar siswa dapat menguasai sejumlah materi pelajaran, akan tetapi bagaimana siswa dapat mengembangkan gagasan-gagasan dan ide-ide melalui kemampuan berbahasa secara verbal. Hal ini didasarkan pada asumsi bahwa kemampuan berbicara secara verbal merupakan salah satu kemampuan berikir, (2) telaah-telaah fakta atau pengalaman merupakan dasar pengembangan kemampuan berpikir, artinya pengembangan gagasan dan ide-ide didasarkan pada pengalaman anak dalam kehidupan sehari-hari atau berdasarkan kemampuan anak untuk mendeskripsikan hasil pengamatan mereka terhadap berbagai fakta dan data yang mereka peroleh dalam kehidupan sehari-hari, dan (3) sasaran SPPKB adalah kemampuan anak untuk memecahkan masalah-masalah yang dihadapinya sesuai dengan taraf perkembangannya.

SPPKB merupakan strategi pembelajara yang bertumpu pada proses perbaikan dan peningkatan kemampuan berpikir siswa.Menurut Peter Reason dalam Wina Sanjaya (2008) berpikir adalah prosesmental seseorang yang lebih sekedar mengingat (remembering) dan memahami (comprehending). Menurut Reason mengingat dan memahami lebih berifat pasif daripada kegiatan berpikir (thinking). Mengingat pada dasarnya hanya melibatkan usaha menyimpan sesuatu yang telah dialami untuk suatu saat dikeluarkan kembali atas permintaan; sedangkan memahami memerlukan pemerolehan apa yang didengar dan dibaca serta melihat keterkaitan antar-aspek dalam memori.

SPPKB menekankan kepada keterlibatan siswa secara penuh dalam belajar. Hal ini sesuai dengan hakikat SPPKB yang tidak mengharapkan siswa sebagai objek belajar yang hanya duduk mendengarkan penjelasan guru kemudian mencatat untuk dihafalkan.

\section{Hakikat Strategi Pembelajaran Ekspositori}

Dalam menggunakan strategi ekspositori ada bebrapa prinsip yang harus dilaksanakan guru. Menurut Wina Sanjaya (2008) Pertama, berorientasi pada tujuan. Penggunaan startegi ini tiada lain untuk mencapai tujaun pembelajaran secara optimal. Oleh karena itu, sebelum startegi ini dirancang maka langkah awal adalah menentukan tujuan yang akan dicapai. Tujuan yang ditetapkan haruslah dalam bentuk tingkah laku yang dapat diukur (Dick dan Carey, 2015). Kedua, prinsip komunikasi. Proses pembelajaran dapat dikatakan sebagai proses komunikasi, yang menunjuk pada proses penyampaian pesan dari seseorang kepada seseorang atau sekelompok orang. Dalam proses komunikasi bagaimanapun sederhananya, selalu terjadi urutan pemindahan pesan dari sumber pesan kepada penerima pesan. Komunikasi dikatakan berhasil apabila pesan yang disampaikan mudah dipahami oleh penerima pesan dan dikuasainya. Ketiga, prinsip kesiapan. Dalam menerapkan strategi ini guru harus memperhatikan kesiapan siswa menerima pesan yang akan disampaikan. Jika siswa tidak memiliki kesiapan maka tujuan akan sulit dicapai. Keempat, prinsip 
berkelanjutan. Penggunaan strategi ini harus mampu mendorong siswa untuk mau mempelajari materi lebih lanjut. Pembelajaran bukan hanya berlangsung pada saat itu saja, tetapi juga untuk waktu selanjutnya.

\section{Hakikat Kemampuan Awal Apresiasi Sastra Prosa Fiksi}

Untuk dapat memahami struktur karya sastra dan dapat merebut makna dengan setepattepatnya seorang pembaca perlu mengenal dan memahami bagian-bagian atau elemen-elemen pembangun karya sastra. Mengapa demikian? Karena, karya sastra merupakan sebuah struktur yang rumit (Wellek dan Warren, 1956). Sebagai sebuah struktur, karya sastra mengandung gagasan keseluruhan, gagasan kaidah yang mandiri (Hawkes, 1978). Oleh karena itu, untuk memahami karya sastra diperlukan analisis terhadap bagian-bagian struktur tersebut. Jadi apresiasi sastra tidak bisa dipisahkan dengan penguasaan terhadap hal-hal yang berkaitan kemampuan mengapresiasi sastra yang salah satunya adalah kemampuan awal tentang apa itu novel, jenis-jenis novel, dan apa-apa unsur pembangun novel.

Untuk mempermudah memahami karya sastra sebagai tujuan dari apresiasi, pembaca terlebih dahulu harus mengetahui apa saja yang harus dilakukannya, misalnya pembaca harus memiliki kemampuan awal tentang karya sastra yang akan diapresiasinya. Penguasaan terhadap teori apresiasi sastra (unsusr-unsur pembengun karya sastra prosa fiksi) merupakan kemampuan awal yang harus dimiliki oleh siswa. Kemampuan awal ini sangat diperlukan untuk dapat mempelajari tugas yang baru. Dick and Carey (2015) mengatakan bahwa kemampuan awal merupakan suatu komponen penting dalam perencanaan pengajaran. Mengemukakan bahwa kemampuan awal (entry behavior) adalah spesifik keoandaian (skill) yang harus dapat didemonstrasikan oleh mahasiswa untuk memasuki suatu aktivitas pengajaran.

Hal ini juga sesuai dengan teori belajar transfer of learning yang dikemukakan oleh Thorndike dalam suryabrata (1983) mengatakan bahwa hal-hal yang telah dipelajari dapat digunakan untuk menghadapi atau memecahkan yang baru. Transfer of learning akan terjadi apabila antara hal yang lama dengan hal yang baru terdapat unsur-unsur yang identik. Menurut Degeng dalam Misno (2006) mengatakan kemampuan awal sangat penting peranannya dalam meningkatkan kebermaknaan pembelajaran, yang selanjutnya membawa dampak dalam memudahkan proses internal yang berlangsung dalam diri pebelajar pada saat belajar.

Berdasarkan pendapat tersebut maka kemampuan awal tentang pengertian novel, jenis-jenis novel dan unsur-unsur pembangun novel tersebut. Menurut Degeng dalam Misno (2006) kemampuan awal sangat penting peranannya dalam meningkatkan kebermaknaan pembelajaran, yang selanjutnya membawa dampak dalam memudahkan proses internal yang berlangsung dalam diri siswa pada saat belajar.

Reigeluth dalam Misno (2006) mengklasifikasikan kemampuan awal menjadi tiga bagian yang didasarkan pada tingkat penguasaannya yaitu (1) kemampuan awal siap pakai, (2) kemapuan awal siap ulang, dan (3) kemampuan pengenalan.

Berdasarkan pembatasan masalah yang telah dikemukakan, maka masalah penelitian ini dapat dirumuskan sebagai berikut: (1) Apakah hasil belajar apresiasi karya sastra prosa fiksi siswa yang dibelajarkan dengan SPPKB lebih tinggi daripada siswa yang dibelajarkan dengan strategi ekspositori?; (2) Apakah hasil belajar apresiasi karya sastra prosa fiksi siswa yang memiliki kemampuan awal apresiasi sastra yang tinggi lebih tinggi daripada yang kemampuan awal apresiasi sastranya rendah; dan (3) Apakah terdapat interaksi antara strategi pembelajaran dengan kemampuan awal apresiasi sastra prosa fiksi siswa terhadap hasil belajar siswa mengapresiasi karya sastra prosa fiksi?

\section{METODE}

Penelitian dan uji coba instrumen penelitian ini dalaksanakan di SMP Negeri 2 Na IX-X Desa Sei Raja Kecamatan Na IX-X Kabupaten Labuhanbatu Utara. Populasi penelitian ini adalah seluruh siswa kelas VIII SMP Negeri 2 Na IX-X Sei Raja yang terdiri dari empat kelas yang berjumlah 122 orang. Distribusi populasi tersebut memiliki karaktristik yang sama khususnya tentang kompetensi, karena dalam pengelompokan kelas tersebut dilakukan secara acak. Sedangkan teknik pengambilan sampel dilakukan dengan teknik cluster random sampling. Teknik ini dipilih karena yang disampling dari populasi adalah jumlah 
rombongan belajar bukan jumlah siswa dalam setiap rombongan belajar dalam populasi.

Sampel yang diambil terdiri dari dua Rombongan belajar yaitu, satu kelompok adalah rombongan belajar yang dilakukan pembelajaran dengan SPPKB dan rombongan belajar satu lagi dibelajarkan dengan strategi ekspositorik. Tenaga pengajar yang ditetapkan untuk melakukan pembelajaran diberikan pembekalan yang dibutuhkan. Sampel yang diambil terdiri dari siswa yang kemampuan awalnya tinggi dan siswa yang kemampuan awalnya rendah, dan kedua rombongan belajar ini tersebar di dua kelas yang dijadikan sampel penelitian.

Metode penelitian yang digunakan dalam penelitian ini adalah eksprimen semu (quasi eksprimen), yaitu dengan mengelompokkan sampel penelitian menjadi dua rombongan belajar atau kelompok, yakni pada kelompok ekspriman (rombel VIII-1) dilakukan dengan pembelajaran SPPBK, dan pada kelompok control (rombel VIII-3) dilakukan dengan strategi pembelajaran ekspositori. Pada akhir penelitian kemampuan mengapresiasi karya sastra prosa fiksi siswa dari dua rombel sampel dibandingkan dan diuji dengan analisis statistik untuk melihat seberapa jauh perbedaan hasil belajar dengan menggunakan kedua strategi tersebut.

Desain penelitian yang direncanakan dalam penelitian ini adalah faktorial $2 \times 2$ sebagaimana terlihat pada Tabel 1 . berikut ini.

Tabel 1. Matrik Rancangan Penelitian

\begin{tabular}{|c|c|c|}
\hline $\begin{array}{l}\text { Pendekatan } \\
\text { Kemampuan } \\
\text { Awal Apresiasi karya sastraProsa fiksi }\end{array}$ & SPPKB (A1) & Ekspositori(A2) \\
\hline Tinggi (B1) & A1B1 & A2B1 \\
\hline Rendah & A1B2 & A2B2 \\
\hline Jumlah & $\mathrm{A} 1 \mathrm{~B} 1+\mathrm{A} 1 \mathrm{~B} 2$ & $\mathrm{~A} 2 \mathrm{~B} 1+\mathrm{A} 2 \mathrm{~B} 2$ \\
\hline
\end{tabular}

Keterangan :

A1B1: Hasil belajar apresiasi karya sastra prosa fiksi siswa yang kemampuan awal apresiasi tinggi yang dibelajarakan dengan menggunakan SPPKB.

A2B1: Hasil belajar apresiasi karya sastra prosa fiksi siswa yang kemampuan awal apresiasi tinggi yang dibelajarkan dengan menggunakan strategi ekspositori.

A1B2: Hasil belajar apresiasi karya sastra prosa fiksi siswa yang kemampuan awal apresiasi karya sastra prosa fiksi rendah yang diajar dngan memnggunakan SPPKB.

A2B2: Hasil Belajar apresiasi karya sastra prosa fiksi siswa yang kemampuan awal apresiasi prosa fiksi rendah yang dibelajarkan dengan strategi ekspositori.

\section{Teknik Analisis Data}

Sebelum menggunakan teknik faktorial untuk menguji hipotesis terlebih dahulu dilakukan uji persyaratan analisis. Dalam uji persyaratan analisis, dilakukan uji normalitas dilakukan dengan menggunakan metode normalitas Lillliefors (Sudjana, 2002:466).
Selanjutnya uji homogenitas dengan menggunakan uji Fisher $(\mathrm{F})$ dan Barlett dengan taraf signifikansi $5 \%$, untuk menguji kesamaan beberapa buah rata-rata atau pengujian kesamaan parians (Sudjana, 2002:261).

Teknik pengujian hipotesis dalam penelitian ini menggunakan analisis varians (Anava) factorial $2 \times 2$ dengan taraf signifikansi 0,05 (Sudjana, 2002:239). Karena hipotesis yang ketiga ternyata signifikan keberartiannya, maka analisis lanjut dilakukan untuk menguji keberartian satu variabel atau kombinasi variabel bebas terhadap variabel terikat. Selanjutnya dengan jumlah responden setiap kelompok sama (n sama) dilakukan Uji Tuckey, Karena tidak adanya sell $n$ tidak sama maka tidak perlu dilakukan Uji Scheffe.

Adapun rumusan hipotesis statistik untuk keperluan pengujian hipotesis adalah sebagai berikut :
1. Ho $: \mu \mathrm{A} 1=\mathrm{uA} 2$
$\mathrm{Ha} \quad: \mu \mathrm{A} 1>\mathrm{uA} 2$
2. Ho : $\mu \mathrm{B} 1=\mathrm{uB} 2$
$\mathrm{Ha}: \mu \mathrm{B} 1>\mathrm{u} \mathrm{B} 2$
3. Ho: $\mathrm{A}><\mathrm{B}=0$
$\mathrm{Ha}: \mathrm{A}><\mathrm{B} \# 0$

Keterangan : 
$\mu$ A1 : Rata-rata hasil belajar Apresiasi Karya Sastra Prosa Fiksi siswa yang dibelajarkan dengan menggunakan SPPKB

$\mu$ A2 : Rata-rata hasil belajar Apresiasi Karya Sastra Prosa Fiksi siswa yang dibelajarkan dengan strategi ekspositori

$\mu$ B1 : Rata-rata hasil belajar Apresiasi Karya Sastra Prosa Fiksi siswa yang kemampuan awal Aparesiasi Karya Sastra Prosa Fiksi tinggi.

$\mu$ B2 : Rata-rata hasil belajar Apresiasi Karya Sastra Prosa Fiksi siswa yang kemampuan awal
Aparesiasi Karya Sastra Prosa Fiksi rendah.

$\mathrm{A}><\mathrm{B}$ : Interaksi strategi pembelajaran dengan kemampuan awal Aparesiasi Karya sastra Prosa Fiksi siswa terhadap hasil belajar Apresiasi Karya Sastra Prosa Fiksi

\section{HASIL DAN PEMBAHASAN \\ Hasil}

Untuk memudahkan pembahasan hasil penelitian perlu dikemukakan terlebih dahulu hasil analisis data secara keseluruhan dalam bentuk tabulasi. Tabulasi tersebut dapat dilihat pada Tabel 2 berikut ini :

Tabel 2. Tabulasi Jumlah Desain Penelitian Anava 2 x 2

\begin{tabular}{|c|c|c|c|}
\hline Kemampuan awal (B) & $\begin{array}{c}\text { SPPKB } \\
\left(\mathrm{A}_{1}\right)\end{array}$ & $\begin{array}{l}\text { Ekspositori } \\
\quad\left(\mathrm{A}_{2}\right)\end{array}$ & Total \\
\hline $\begin{array}{l}\text { Tinggi } \\
\left(\mathrm{B}_{1}\right)\end{array}$ & $\begin{aligned} \mathrm{N}_{11} & =15 \\
\mathrm{X}_{11} & =29,87 \\
\sum_{11} X_{11} & =448 \\
\sum_{\mathrm{S}} X_{2} & =1346 \\
& =2,42\end{aligned}$ & $\begin{aligned} \mathrm{N}_{21} & =15 \\
\mathrm{X}_{21} & =25,40 \\
\sum_{21} X_{21} & =381 \\
\sum_{\mathrm{S}} X_{2} & =9741 \\
& =2,13\end{aligned}$ & 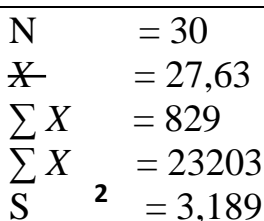 \\
\hline $\begin{array}{c}\text { Rendah } \\
\left(\mathrm{B}_{2}\right)\end{array}$ & $\begin{aligned} \mathrm{N}_{11}{ }_{11} & =15 \\
X_{11} & =18,33 \\
\sum_{11} X_{11} & =275 \\
\sum_{S} X_{2} & =5177 \\
S_{2} & =3,11\end{aligned}$ & $\begin{aligned} \mathrm{N}_{22}{ }_{21} & =15 \\
X_{22} & =19,33 \\
\sum_{22} X_{22} & =290 \\
\sum_{\mathrm{S}} X_{2} & =5804 \\
& =3.75\end{aligned}$ & $\begin{array}{ll}\mathrm{N} & =30 \\
X & =18,83 \\
\sum X & =565 \\
\sum \sum_{\mathrm{S}}{ }^{2} & =10981 \\
& =3.42\end{array}$ \\
\hline Total & \begin{aligned} $\mathrm{N} & \multicolumn{11}{l}{=30} \\
X & =24,10 \\
\sum_{11} X_{11} & =723 \\
\sum_{\mathrm{S} X} X_{2} & =18639 \\
& =6,47\end{aligned}$ & 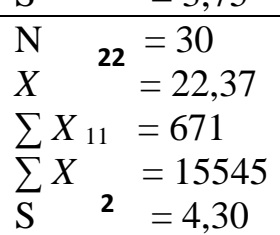 & $\begin{array}{ll}\mathrm{N}_{\mathrm{t}} & =60 \\
X_{\mathrm{t}} & =23,23 \\
\sum X & =1394 \\
\sum_{\mathrm{S}} X & =34184 \\
\mathrm{~S} & =5,52\end{array}$ \\
\hline
\end{tabular}

Pengujian hipotesi penelitian dilakukan dengan menggunakan Anava 2 x $2 . \quad$ Secara keseluruhan tabel ANAVA dua jalur untuk pengujian hipotesis dapat dilihat pada Tabel 3. di bawah ini:

Tabel 3. Rangkuman ANAVA Faktorial $2 \times 2$

\begin{tabular}{|c|c|c|c|c|c|}
\hline Sumber Variasi & DK & JK & RJK & $\mathrm{F}_{\text {hitung }}$ & $\mathrm{F}_{\text {table }} \mathrm{a}=0,05$ \\
\hline Strategi Pembelajaran & 1 & 45,07 & 45,07 & 5,28 & 4,01 \\
\hline Kemampuan Awal & 1 & 1161,60 & 1161,60 & 136,02 & \\
\hline Interaksi & 1 & 112,06 & 112,06 & 13,12 & \\
\hline Galat & 56 & 478,00 & 8,54 & & \\
\hline Total & 59 & 1796,73 & & & \\
\hline
\end{tabular}

Dari Tabel di atas dapat kita lihat penjelasan hipotesis yang yang diuji seperti yang diuraikan dibawah ini:
1. Hasil Belajar Apresiasi Sastra Prosa Fiksi Siswa yang Dibelajarkan dengan SPPKB Lebih Tinggi daripada Hasil Belajar Apresiasi Karya Sastra Prosa Fiksi yang Dibelajarkan dengan Startegi Ekspositori 


$\begin{array}{cccc}\text { Ho } & : & \mu \mathrm{A} 1= & \mu \mathrm{A} 2 \\ \mathrm{Ha} & : & \mu \mathrm{A} 1> & \mu \mathrm{A} 2 \\ \text { Rata-rata } & \text { hasil belajar } & \text { Apresiasi }\end{array}$

Sastra Prosa Fiksi dengan SPPKB 24,10 dan rata-rata hasil belajar Apresiasi Sastra Prosa Fiksi dengan strategi ekspositori 22,37. Hasil perhitungan ANAVA pada tabel 4.13, diperoleh $F_{\text {hitung }}=5,28$. Sementara nilai kritik $F_{\text {tabel }}$ pada taraf signifikansi 0,05 adalah sebesar 4,01. Hasil ini menunjukkan bahwa $\mathrm{F}_{\text {hitung }}=5,28>\mathrm{F}$ tabel $=4,01$, sehingga hipotesis nol (Ho) ditolak dan Ha diterima. Dengan demikian hipotesis penelitian yang menyatakan bahwa hasil belajar Apresiasi Sastra Prosa Fiksi siswa yang dibelajarkan dengan SPPKB lebih tinggi daripada hasil belajar Apresiasi Sastra Prosa Fiksi siswa yang dibelajarkan dengan startegi ekspositori telah teruji kebenarannya.

Dari hasil pengujian diperoleh kesimpulan bahwa hasil belajar Apresiasi Sastra Prosa Fiksi Siswa dengan SPPKB lebih tinggi daripada hasil belajar Apresiasi Sastra Prosa Fiksi siswa dengan strategi ekspositori.

2. Hasil Belajar Apresiasi Sastra Prosa Fiksi siswa yang mempunyai Kemampuan Awal Tinggi Lebih tinggi daripada Hasil Belajar Apresiasi Sastra Prosa Fiksi siswa yang Memiliki Kemampuan Awal Rendah.

$$
\begin{aligned}
& \text { Ho : } \mu \mathrm{B} 1=\mu \mathrm{B} 2 \\
& \mathrm{Ha}: \mu \mathrm{B} 1>\mu \mathrm{B} 2
\end{aligned}
$$

Rata-rata hasil belajar Apresiasi

Sastra Prosa Fiksi siswa yang memiliki kemampuan awal tinggi adalah 27,63 dan ratarata hasil belajar Apresiasi Sastra Prosa Fiksi siswa yang memiliki kemampuan awal rendah sebesar 18,83. Hasil perhitungan ANAVA diperoleh hasil perhitungan data kemampuan awal tinggi, dimana $F$ hitung $=136,02$ dan nilai $\mathrm{F}_{\text {tabel }}$ pada taraf signifikansi 0,05 adalah sebesar 4,01. Hasil ini menunjukkan bahwa $\mathrm{F}$ hitung $=$ $136,02>\mathrm{F}$ tabel $=4,01$, sehigga hipotesis nol (Ho) ditolak dan Ha diterima. Dengan demikian hipotesis penelitian yang menyatakan bahwa hasil belajar Apresiasi Sastra Prosa Fiksi siswa yang memiliki kemampuan awal Apresiasi Sastra Prosa Fiksi siswa tinggi lebih tinggi daripada yang memiliki kemampuan awal Apresiasi Sastra Prosa Fiksi siswa rendah telah teruji kebenarannya.

Dari hasil pengujian diperoleh kesimpulan bahwa hasil belajar Apresiasi Sastra Prosa Fiksi siswa yang memiliki kemampuan awal tinggi lehih tinggi daripada hasil belajar Apresiasi Sastra Prosa Fiksi siswa yang memiliki kemampuan awal rendah.

3. Ada Interaksi Antara Strategi Pembelajaran dan Kemampuan Awal Dalam Mempengaruhi Hasil Belajar Apresiasi Karya Sastra Prosa Fiksi Siswa

$$
\begin{aligned}
& \text { Ho : } \quad \mathrm{A}><\mathrm{B}=0 \\
& \mathrm{Ha} \quad \text { : } \quad \mathrm{A}><\mathrm{B} \neq 0 \\
& \text { Rata-rata hasil belajar Apresiasi }
\end{aligned}
$$

Sastra Prosa Fiksi siswa dengan pemberian SPPKB dan kemampuan awal tinggi sebesar 29,87, rata-rata hasil belajar Apresiasi Sastra Prosa Fiksi siswa dengan SPPKB dengan kemampuan awal rendah sebesar 18,33, ratarata hasil belajar Apresiasi Sastra Prosa Fiksi siswa dengan strategi ekspositori dan kemampuan awal tinggi sebesar 25,40, rata-rata hasil belajar Apresiasi Sastra Prosa Fiksi siswa dengan strategi ekspositori dan kemampuan awal rendah sebesar 19,33. Dari perhitungan ANAVA diperoleh hasil perhitungan data tentang interaksi antara strategi pembelajaran dan kemampuan awal siswa, di mana $\mathrm{F}_{\text {hitung }}=$ 13,12 dan nilai kritik $F$ tabel pada taraf signifikansi 0,05 adalah sebesar 4,01, dengan demikian hipotesis nol (Ho) ditolak dan hipotesis penelitian yang menyatakan bahwa terdapat interaksi antara strategi pembelajaran dan kemampuan awal siswa terhadap hasil belajar Apresiasi Sastra Prosa Fiksi siswa teruji kebenarannya.

Berdasarkan data rata-rata hasil belajar Apresiasi Sastra Prosa Fiksi siswa di atas dapat dilihat bahwa antara SPPKB dan strategi ekspositori dengan kemampuan awal tinggi dan interaksi antara strategi pembelajaran dan kemampuan awal terhadap hasil belajar Apresiasi Sastra Prosa Fiksi siswa, dapat dilihat pada Gambar 1 berikut ini 


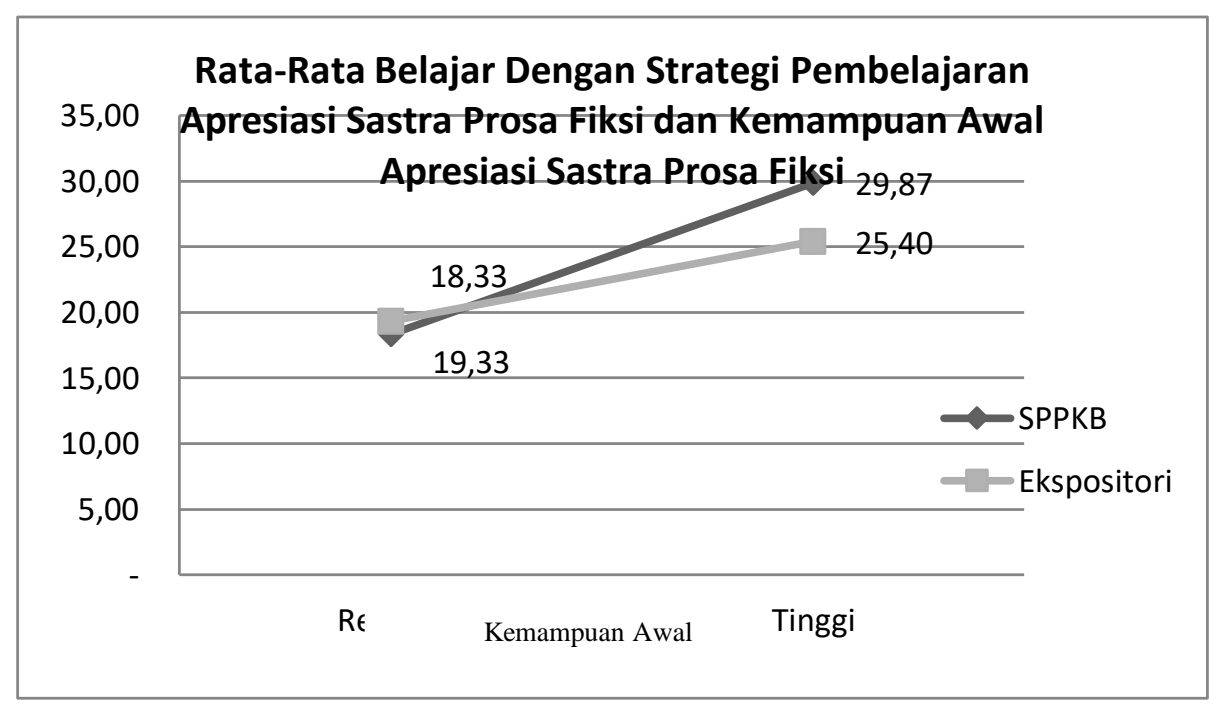

Gambar 1. Rata-rata Hasil Belajar Dengan Strategi pembelajaran dan Kemampuan Awal

Adanya interaksi antara strategi pembelajaran dan kemampuan awal dalam mempengaruhi hasil belajar Apresiasi Sastra Prosa Fiksi siswa , perlu uji diperiksa kembali dengan menggunakan uji Tuckey (lampiran 11) . hipotesis pasangan statistik yang diuji yaitu :

$$
\begin{array}{lll}
\mathrm{Ho} & : & \mu \mathrm{A} 1 \mathrm{~B} 1=\mu \mathrm{A} 2 \mathrm{~B} 1 \\
\mathrm{Ha} & : & \mu \mathrm{A} 1 \mathrm{~B} 1>\mu \mathrm{A} 2 \mathrm{~B} 1
\end{array}
$$

Dimana interaksi antara strategi pembelajaran dan kemampuan awal dalam mempengaruhi hasil belajar Apresiasi Sastra Prosa Fiksi siswa diperoleh $\mathrm{F}$ hitung $=5,92$ dan nilai kritik $\mathrm{F}$ tabel pada taraf signifikansi 0,05 adalah sebesar 2,14. Hal ini menunjukkan bahwa $\mathrm{F}_{\text {hitung }}=5,92>\mathrm{F}_{\text {tabel }}=2,14$, dengan demikian hipotesis penelitian yang menyatakan bahwa terdapat interaksi antara strategi

pembelajaran dan kemampuan awal dalam mempengaruhi hasil belajar Apresiasi Sastra Prosa Fiksi siswa dapat diterima.

$$
\begin{array}{lll}
\text { Ho } & : & \mu \mathrm{A} 1 \mathrm{~B} 2=\mu \mathrm{A} 2 \mathrm{~B} 2 \\
\mathrm{H} 1 & : & \mu \mathrm{A} 1 \mathrm{~B} 2>\mu \mathrm{A} 2 \mathrm{~B} 2
\end{array}
$$

Dimana interaksi antara strategi pembelajaran dan kemampuan awal dalam mempengaruhi hasil belajar Apresiasi Sastra Prosa Fiksi siswa diperoleh $\mathrm{F}$ hitung $=1,33$ dan nilai kritik $F$ tabel pada taraf signifikansi 0,05 adalah sebesar 2,14. Hal ini menunjukkan bahwa $\mathrm{F}$ hitung $=1,33 \leq \mathrm{F}$ tabel $=2,14$, dengan demikian hipotesis penelitian yang menyatakan bahwa terdapat interaksi antara strategi pembelajaran dan kemampuan awal dalam mempengaruhi hasil belajar Apresiasi Karya sastraProsa Fiksi siswa tidak dapat diterima.

$$
\text { Ho } \quad: \quad \mu \mathrm{A} 1 \mathrm{~B} 1=\mu \mathrm{A} 1 \mathrm{~B} 2
$$

\section{H1 $\quad: \quad \mu \mathrm{A} 1 \mathrm{~B} 1>\mu \mathrm{A} 1 \mathrm{~B} 2$}

Dimana interaksi antara strategi pembelajaran dan kemampuan awal dalam mempengaruhi hasil belajar Apresiasi Sastra Prosa Fiksi siswa diperoleh $\mathrm{F}_{\text {hitung }}=15,29$ dan nilai kritik $\mathrm{F}_{\text {tabel }}=$ pada taraf signifikansi 0,05 adalah sebesar 2,14. Hal ini menunjukkan bahwa $F_{\text {hitung }}=15,29>F_{\text {tabel }}=2,14$, dengan demikian hipotesis penelitian yang menyatakan bahwa terdapat interaksi antara strategi pembelajaran dan kemampuan awal dalam mempengaruhi hasil belajar Apresiasi Sastra Prosa Fiksi siswa dapat diterima.

$$
\begin{array}{llll}
\text { Ho } & : & \mu \mathrm{A} 2 \mathrm{~B} 1=\mu \mathrm{A} 2 \mathrm{~B} 2 \\
\mathrm{H} 1 & : & \mu \mathrm{A} 1 \mathrm{~B} 1>\mu \mathrm{A} 2 \mathrm{~B} 2
\end{array}
$$

Dimana interaksi antara strategi pembelajaran dan kemampuan awal dalam mempengaruhi hasil belajar Apresiasi Sastra Prosa Fiksi siswa diperoleh $\mathrm{F}$ hitung $=8,64$ dan nilai kritik $F$ tabel pada taraf signifikansi 0,05 adalah sebesar 2,14. Hal ini menunjukkan bahwa $\mathrm{F}$ hitung $=8,64>\mathrm{F}$ tabel $=2,14$, dengan demikian hipotesis penelitian yang menyatakan bahwa terdapat interaksi antara strategi pembelajaran dan kemampuan awal dalam mempengaruhi hasil belajar Apresiasi Sastra Prosa Fiksi siswa dapat diterima.

$$
\begin{array}{lll}
\text { Ho } & : & \mu \mathrm{A} 1 \mathrm{~B} 1=\mu \mathrm{A} 2 \mathrm{~B} 2 \\
\mathrm{H} 1 & : & \mu \mathrm{A} 1 \mathrm{~B} 1>\mu \mathrm{A} 2 \mathrm{~B} 2
\end{array}
$$

Dimana interaksi antara strategi pembelajaran dan kemampuan awal dalam mempengaruhi hasil belajar Apresiasi Sastra Prosa Fiksi siswa diperoleh $\mathrm{F}$ hitung $=13,96$ dan nilai kritik $F$ tabel pada taraf signifikansi 0,05 adalah sebesar 2,14. Hal ini menunjukkan bahwa $\mathrm{F}$ hitung $=13,96>\mathrm{F}$ tabel $=2,14$, dengan 
demikian hipotesisi penelitian yang menyatakan bahwa terdapat interaksi antara strategi pembelajaran dan kemampuan awal dalam mempengaruhi hasil belajar Apresiasi Sastra Prosa Fiksi siswa dapat diterima.

$$
\begin{array}{lll}
\text { Ho } & : & \mu \mathrm{A} 1 \mathrm{~B} 2=\mu \mathrm{A} 2 \mathrm{~B} 1 \\
\mathrm{H} 1 & : & \mu \mathrm{A} 1 \mathrm{~B} 2>\mu \mathrm{A} 2 \mathrm{~B} 1
\end{array}
$$

Dimana interaksi antara strategi pembelajaran dan kemampuan awal dalam mempengaruhi hasil belajar Apresiasi Sastra Prosa Fiksi siswa diperoleh $\mathrm{F}_{\text {hitung }}=9,37$ dan nilai kritik $F$ tabel pada taraf signifikansi 0,05 adalah sebesar 2,14. Hal ini menunjukkan bahwa $\mathrm{F}_{\text {hitung }}=9,37>\mathrm{F}$ tabel $=2,14$, dengan demikian hipotesis penelitian yang menyatakan bahwa terdapat interaksi antara strategi pembelajaran dan kemampuan awal dalam mempengaruhi hasil belajar apresiasi sastra prosa fiksi siswa dapat diterima.

Rangkuman dari uji lanjut interaksi antara staretgi pembelajaran dan kemampuan awal dalam mempengaruhi hasil belajar Apresiasi Karya Sastra Prosa Fiksi siswa dengan uji Tuckey dapat dilihat pada tabel 4. di bawah ini

Tabel. Rangkuman Uji Lanjut dengan Uji Tuckey.

\begin{tabular}{|c|c|c|c|}
\hline $\begin{array}{c}\text { Skor Kelompok yang } \\
\text { Dibandingkan }\end{array}$ & $\mathrm{F}_{\text {hitung }}$ & $\begin{array}{c}\mathrm{F}_{\text {tabel }} \\
\mathrm{a}=0,05\end{array}$ & Keterangan \\
\hline$\mu \mathrm{A} 1 \mathrm{~B} 1$ dengan $\mu \mathrm{A} 2 \mathrm{~B} 1$ & 5,92 & 2,14 & Signifikan \\
\hline$\mu \mathrm{A} 1 \mathrm{~B} 2$ dengan $\mu \mathrm{A} 2 \mathrm{~B} 2$ & 1,33 & 2,14 & Tidak Signifikan \\
\hline$\mu \mathrm{A} 1 \mathrm{~B} 1$ dengan $\mu \mathrm{A} 1 \mathrm{~B} 2$ & 15,29 & 2,14 & Signifikan \\
\hline$\mu \mathrm{A} 2 \mathrm{~B} 1$ dengan $\mu \mathrm{A} 2 \mathrm{~B} 2$ & 8,64 & 2,14 & Signifikan \\
\hline$\mu \mathrm{A} 1 \mathrm{~B} 1$ dengan $\mu \mathrm{A} 2 \mathrm{~B} 1$ & 13,96 & 2,14 & Signifikan \\
\hline$\mu \mathrm{A} 2 \mathrm{~B} 1$ dengan $\mu \mathrm{A} 2 \mathrm{~B} 1$ & 9,37 & 2,14 & Signifikan \\
\hline
\end{tabular}

\section{Pembahasan}

Hasil Belajar Apresiasi Karya Sastra Prosa Fiksi Siswa dengan SPPKB Lebih Tinggi daripada Strategi Ekspositori.

Untuk membuat siswa semakin siap mengikuti pembelajaran pada kompetensi ini, guru harus mampu merancang strategi pembelajaran yang tepat. Menggunakan SPPKB membuat siswa semakin mandiri dan kreatif dalam memecahkan masalah, pembelajaran dengan SPPKB lebih baik. Hal ini sesuai dengan yang dikemukakan Wina sanjaya (2008) keterlibatan siswa secara aktif dalam belajar sangat dipentingkan, karena hanya dengan mengaktifkan siswa maka proses asimilasi dan akomodasi pengetahuan dan pengalaman dapat terjadi dengan baik.

Dengan SPPKB siswa akan semakin mampu meningkatkan kemampuan bernalarnya untuk menyelesaikan tugas belajarnya. Dengan meningkatnya kemampuan bernalarnya , akan memunculkan keinginanan siswa untuk berhasil dalam studinya. Hal ini Sesuai dengan hasil penelitian-penelitian sebelumnya bahwa pembelajaran yang berpusat pada siswa akan memperoleh hasil belajar yang lebih tinggi, dibandingkan dengan pembelajaran yang menjadikan guru sebagai pusat belajar. Siswa yang memiliki kemampuan awal tinggi memperoleh hasil belajar yang lebih tinggi dibandingkan dengan siswa yang memiliki kemampuan awal rendah, dan ditemukan ada kaitan antara strategi pembelajaran dan kemampuan awal dalam mempengaruhi hasil belajar.

Disamping itu dengan SPPKB akan mendorong siswa untuk berupaya menyelesaikan tugas belajarnya sendiri, Hal ini dosebabkan munculnya rasa percaya diri dengan kemampuan berpikir yang dimilikinya. Sementara itu, pembelajaran dengan strategi ekspositori cenderung membuat siswa kurang memiliki rasa percaya diri untuk menyelesaikan tugasnya. Hal ini karena siswa terbiasa hanya menerima bantuan dari guru. Siswa tidak terbiasa memikirkan sendiri tugas belajarnya. Daya berpikirnya tidak terlatih sehingga jika dihadapkan kepada masalah tugas belajar siswa akan merasa kesulitan menyelesaikannya.

Kondisi-kondisi inilah yang menyebabkan strategi ekspositori tidak cukup membantu siswa dalam mengapresiasi karya sastra prosa fiksi dengan baik, dengan demikian dapat dikatakan gawa SPPKB lebih baik mempengaruhi hasil belajar siswa dibandingkan dengan strategi ekspositori.

Hasil Belajar Siswa yang Mempunyai Kamampuan Awal Tinggi Lebih Tinggi daripada Kemampuan Awal Rendah

Hasil belajar kelompok sampel yang memiliki kemampuan awal tinggi lebih unggul 
daripda kelompok sampel yang memiliki kemampuan awal rendah, . Hal ini sesuai dengan yang dikemukakan oleh Dageng dalam Misno (2006) mengatakan kemampuan awal sangat penting peranannya dalam meningkatkan kebermaknaan pembelajaran, yang selanjutnya membawa dampak dalam memudahkan proses internal yang berlangsung dalam diri pebelajar pada saat belajar. Dick (2015) mengatakan bahwa kemampuan awal merupakan suatu komponen penting dalam perencanaan pengajaran.

Pertumbuhan dan perkembangan kemampuan awal seseorang akan mempengaruhi faktor kematangan dalam belajar. Siswa adalah peserta dididk yang mempunyai kemampuan dalam mengikuti sistem pembelajaran. Tingkat kemampuan awal yang mulai tumbuh atau justru telah tampak dalam kegiatan sehari-hari, akan memberikan dukungan terhadap kegiatan belajar yang dilakukannya. Kemampuan awal sebagai sesuatu pada diri individu dalam melakukan sesuatu tanpa ketergantungan pada orang lain. Dengan adanya kemampuan awal, seorang siswa akan memiliki kemampuan untuk mengajukan berbagai pendekatan pemecahan masalah-masalah apresiasi karya sastra prosa fiksi secara berani, mampu melahirkan berbagai gagasan dan mampu menguraikan secara terperinci. Dengan kata lain kemampuan awal yang tinggi sangat bermanfaat bagi perkembangan intelegensi dan perkembangan pribadi seseorang dalam menghadapi persoalanpersoalan tugas belajar.

Sebaliknya pada kelompok sampel yang memiliki kemampuan awal rendah akan mengalami kesulitan untuk membangun atau mengkonstruksi pengetahuan dan keterampilan mengapresiasi karya sastra prosa fiksi yang dibutuhkannya. Sebab siswa dengan kemampuan awal yang rendah memiliki kecenderungan kurang mampu dalam mengoptimalkan seluruh potensi yang dimilikinya untuk kemudian digunakan dalam mempelajari apresiasi karya sastra prosa fiksi. Siswa dengan kemampuan awal rendah cenderung kurang memiliki keyakinan untuk melahirkan sesuatu yang baru, baik berupa gagasan maupun karya nyata yang relatif berbeda dengan apa yang sebelumnya telah ada, dan pada akhirnya mahasiswa tersebut akan mengalami kesulitan-kesulitan dalam mengikuti materi pembelajaran apresiasi karya sastra prosa fiksi.
Terdapat Interaksi antara Strategi Pembelajaran dan Kemampuan Awal terhadap Hasil Belajar Apresiasi Karya Sastra Prosa Fiksi

Apresiasi Karya Sastra Prosa Fiksi merupakan materi pembelajaran yang mendidik dan melatih siswa dalam menemukan masalahmasalah konstruksi melalui pemahaman , penalaran, analisis, serta kemampuan menstransfer apa yang telah didapat. Hal ini disebabkan karena terdapat interaksi antara strategi pembelajaran dan kemampuan awal memiliki potensi untuk memberikan pengaruh terhadap pencapaian hasil belajar Apresiasi Karya Sastra Prosa Fiksi. Mengingat luasnya cakupan materi ini baik dari segi perspektif teoritis maupun perspektif praktis, menuntut dibutuhkannya suatu kesiapan yang baik pada diri siswa untuk mempelajari ini secara baik. Kesiapan untuk memecahkan masalah-masalah dalam bidang apresiasi karya sastra prosa fiksi , merumuskannya, dan membuat kesimpulan pemecahan masalah didasarkan atas teori-teori yang telah dipelajari yang berkaitan dengan dunia sastra.

Karakteristik apresiasi karya sastra prosa fiksi sedikit berbeda dibandingkan dengan materi-materi pembelajaran lainnya, karena pada bidang ini kemampuan bernalar dan analisis sangat dilibatkan, oleh karenanya, SPPKB sangat tepat untuk membuat siswa semakin siap untuk mempelajari materi ini. Hal ini dikarenakan SPPKB adalah suatu strategi yang menekankan kepada proses keterlibatan siswa secara penuh keyakinan dan kepercayaan untuk dapat memecahkan tugas belajar yang dipelajari dan menghubungkannya dengan situasi kehidupan nyata sehingga mendorong siswa untuk dapat menerapkannya dalam kehidupan sehari-hari. Oleh karenanya, SPPKB menuntut adanya kemampuan awal yang tinggi dalam diri siswa. Adanya kemampuan awal yang tinggi akan melahirkan kemampuan, keyakinan untuk melakukan dan mengerjakan tugas-tugas belajar. Disamping itu, kemampuan awal yang tinggi juga akan memunculkan rasa tanggung jawab dan motivasi yang tinggi, sehingga siswa akan terus terpacu untuk mengerjakan tugas-tugasnya.

Dari perhitungan uji lanjut ini, ternyata kemampuan awal tinggi menentukan keberhasilan penerapan SPPKB. Hal ini kemampuan awal siswa yang tinggi mesti ada dalam diri siswa sebagai prasyarat terlaksananya pembelajaran dengan SPPKB, 
diamana kesiapan ini mendorong siswa menemukan hubungan antara materi yang dipelajari dengan situasi kehidupan nyata, artinya siswa dituntut untuk dapat menangkap hubungan antara pengalaman belajar ditempat dengan kehidupan nyata, dan mampu menerapkannya pada waktu yang lain.

\section{PENUTUP}

Berdasarkan hasil pengujian hipotesis yang dilakukan dalam penelitian ini, maka sebagai simpulan penelitian ini adalah

1. Terdapat perbedaan hasil belajar Apresiasi Karya Sastra Prosa Fiksi antara siswa yang dibelajarkan dengan menggunakan SPPKB dan startegi ekspositori, dalam hal ini siswa yang dibelajarkan dengan menggunakan SPPKB lebih tinggi hasil belajarnya dibandingkan dengan hasil belajar siswa yang dibelajarkan dengan strategi ekspositori.

2. Terdapat perbedaan hasil belajar Apresiasi Karya Sastra Prosa Fiksi antara siswa yang mempunyai kemampuan awal tinggi dengan siswa yang mempunyai kemampuan awal rendah. Dalam hal ini, hasil belajar siswa yang mempunyai kemampuan awal tinggi lebih tinggi dibanding dengan hasil belajar dari siswa yang mempunyai kemampuan awal rendah.

3. Terdapat interaksi antara strategi pembelajaran dan kemampuan awal terhadap hasil belajar Apresiasi Karya Sastra Prosa Fiksi. Berdasarkan hasil perhitungan dan uji lanjut diperoleh bagi siswa yang mempunyai kemampuan awal tinggi dan diberi perlakuan pembelajaran dengan SPPKB memiliki rata-rata hasil belajar Apresiasi Karya Sastra Prosa Fiksi, sedangkan bagi siswa yang mempunyai kemampuan awal rendah dan dibelajarkan dengan strategi ekspositori memiliki ratarata hasil belajar apresiasi karya sastra prosa fiksi.

\section{DAFTAR PUSTAKA}

Abrahams, M.H. (1981). A Glossary of Literary Teruns. New York : Holt, Rinehart and Wiston.

Arsyad, Azhar. (2000). Media Pengajaran. Jakarta : Raja Grafindo Persada.

Degeng, (199)8. Ilmu Pengajaran Taksonomi Variabel. Jakarta : Direktorat Jendral
Pendidikan Tinggi Departemen Pendidikan Nasional.

Dick, W. \& Carey, L. (2015). The Sistematic Design of Intruction. London : Cott, Foresman and Compani.

Dimiyati dan Mujiono. (2002). Belajar dan Pembelajaran. Jakarta: Rineka Cipta.

Hamalik, K. (2007). Kurikulum dan Pembelajaran. Jakarta : Bumi Aksara.

Hawkes, Terence. (1978). Structuralism and Semiotics. Great Britain: Richard Clay Ltd, Bungay, Suffolk.

Merrill, David. (1981 ). Instructional Components and Strategtes. Los Angeles: University of Southern California.

Merril, M.D. dan Twitchel, D.G. (1994). Intructional Design Theory. New Jersey : Englewood Cliffs.

Misno. (2006). Pengaruh Penggunaan Alat Bantu Pem belajaran dan kemampuan Awal Siswa terhadap Hasil Belajar Peta pada Mata Pelajaran Geografi Siswa SMP Negeri 1 Labuhan Deli. Medan : Tesis PPS Unimed.

Purwanto, N. (2002). Prinsip-prinsip dan teknik evaluasi pembelajaran. Bandung: Rosdakarya.Bloom dalam Purwanto (2000)

Romizowski, A.Z. (1981). Designing Intructional System. New York : Nichol Publishing Company.

Sanjaya, Wina. (2008). Perencanaan dan desain sistem pembelajaran. Jakarta: Kencana Prenada Media Group.

Seels, B.C. dan Richey, R.C. (1994). Intructional Technoligi, The Defenition and Domains of the Fielt. Washington Terjemahan Yusufhadi Marso dkk.

Stanton, Robert. 1965. An Intruktion to Fiction. New York: Holt, Rinehart and Winston.

Sudjana, Nana. (2002). Metode Statistik. Bandung Transito.

Sudjana, N. (2004). Dasar-dasar Proses Belajar Mengajar. Bandung: Remaja Rosda karya.

Suryabrata Sumadi. (1993). Psikologi Pendidikan. Jakarta. PT. Raja Grafindo Persada.

Teeuw, A. (1980). Membaca dan Menilai Sastra. Jakarta : Gramedia.

Wellek, Rene dan Austin. (1956) Theory of Literature, Harmonswort. 